\title{
Silvimonas terrae gen. nov., sp. nov., a novel chitin- degrading facultative anaerobe belonging to the 'Betaproteobacteria'
}

\author{
Hee-Chan Yang, ${ }^{1}$ Wan-Taek Im, ${ }^{1}$ Dong-Shan An, ${ }^{1}$ Woo-shin Park, ${ }^{2}$ \\ In S. Kim ${ }^{2}$ and Sung-Taik Lee ${ }^{1}$ \\ ${ }^{1}$ Department of Biological Sciences, Korea Advanced Institute of Science and Technology, \\ 373-1, Guseong-dong, Yuseong-gu, Daejeon 305-701, South Korea \\ ${ }^{2}$ Department of Environmental Science and Engineering, Gwangju Institute of Science and \\ Technology, 1 Oryong-dong, Buk-gu, Gwangju 500-712, South Korea
}

Correspondence

Sung-Taik Lee

e_stlee@kaist.ac.kr

\begin{abstract}
A taxonomic study was carried out on a bacterial strain, designated $\mathrm{KM}-45^{\top}$, isolated from forest soil collected near Daejeon, South Korea. Comparative 16S rRNA gene sequence analysis indicated a clear affiliation of this bacterium to the 'Betaproteobacteria' and that it was related most closely to Chitinibacter tainanensis BCRC $17254^{\top}$, Formivibrio citricus DSM $6150^{\top}$ and lodobacter fluviatilis ATCC $33051^{\top}(92 \cdot 4,91 \cdot 2$ and 88.9\% 16S rRNA gene sequence similarity, respectively). Cells were Gram-negative, facultatively anaerobic, motile and rod-shaped.

The strain grew well on R2A medium and utilized a broad spectrum of carbon sources. The $\mathrm{G}+\mathrm{C}$ content of the genomic DNA was $58 \mathrm{~mol} \%$ and the predominant ubiquinone was Q-8. Major fatty acids were $\mathrm{C}_{16: 0}, \mathrm{C}_{16: 1} \omega 7 \mathrm{c} /$ iso- $\mathrm{C}_{15: 0} 2-\mathrm{OH}, \mathrm{C}_{18: 1} \omega 7 \mathrm{c} / \omega 9 \mathrm{t} / \omega 12 t$ and $\mathrm{C}_{17: 0}$ cyclo. On the basis of the evidence presented, it is proposed that strain $\mathrm{KM}-45^{\top}$ should be placed in a novel genus and species, for which the name Silvimonas terrae gen. nov., sp. nov. is proposed. The type strain is $\mathrm{KM}-45^{\top}\left(=\mathrm{KCTC} 12358^{\top}=\mathrm{NBRC} 100961^{\top}\right)$.
\end{abstract}

During the course of a study on the culturable aerobic and facultatively anaerobic bacterial community of forest soil and rice fields near Daejeon, South Korea, a large number of novel bacterial strains were isolated. One of these isolates, strain $\mathrm{KM}-45^{\mathrm{T}}$, was identified as belonging to the family Neisseriaceae in the 'Betaproteobacteria' lineage and was the subject of further taxonomic investigation. We report on its taxonomic position, including genotypic, chemotaxonomic and classical phenotypic characteristics, in order to establish its phylogenetic affiliation, and propose that strain $\mathrm{KM}-45^{\mathrm{T}}$ should be placed in a novel genus and species, for which the name Silvimonas terrae gen. nov., sp. nov. is proposed.

Strain $\mathrm{KM}-45^{\mathrm{T}}$ was isolated from forest soil collected near the Korea Advanced Institute of Science and Technology (KAIST) in Daejeon, South Korea. The soil was homogenized by using an Ace Homogenizer (Nihonseiki Kaisha Ltd). The suspension was spread on R2A agar plates (Difco) after being diluted serially with $50 \mathrm{mM}$ phosphate buffer $(\mathrm{pH} 7 \cdot 0)$. The plates were incubated at $30^{\circ} \mathrm{C}$ for 2 weeks. Single colonies on the plates were purified by transferring them onto new plates and incubating again under the same conditions. The isolate was cultured routinely on R2A agar

The GenBank/EMBL/DDBJ accession number for the 16S rRNA gene sequence of strain $\mathrm{KM}-45^{\top}$ is $\mathrm{AB} 194302$. at $30{ }^{\circ} \mathrm{C}$ and maintained as a glycerol suspension $(20 \%$, $\mathrm{w} / \mathrm{v})$ at $-70^{\circ} \mathrm{C}$.

Extraction of genomic DNA was performed by using a commercial genomic DNA extraction kit (Core Biosystem), and PCR-mediated amplification of the 16S rRNA gene and sequencing of the purified PCR product were carried out according to the methods given by Kim et al. (2005). The full-length 16S rRNA gene sequences were compiled by using SeqMan software (DNASTAR). 16S rRNA gene sequences of related taxa were obtained from GenBank. Multiple alignments were performed by using the CLUSTAL_X program (Thompson et al., 1997). Gaps were edited in the BIOEDIT program (Hall, 1999). Evolutionary distances were calculated by using the Kimura twoparameter model (Kimura, 1983). Phylogenetic trees were constructed by using the neighbour-joining (Saitou \& Nei, 1987) and maximum-parsimony (Fitch, 1971) methods, using the MEGA3 program (Kumar et al., 2004) with bootstrap values based on 1000 replications (Felsenstein, 1985).

A nearly complete $16 \mathrm{~S}$ rRNA gene sequence of strain $\mathrm{KM}-45^{\mathrm{T}}$ was obtained (1491 bp). Preliminary comparison against the 16S rRNA gene sequences in GenBank indicated that strain $\mathrm{KM}-45^{\mathrm{T}}$ belonged to the order 'Neisseriales' of the 'Betaproteobacteria'. On the basis of 16S rRNA gene 


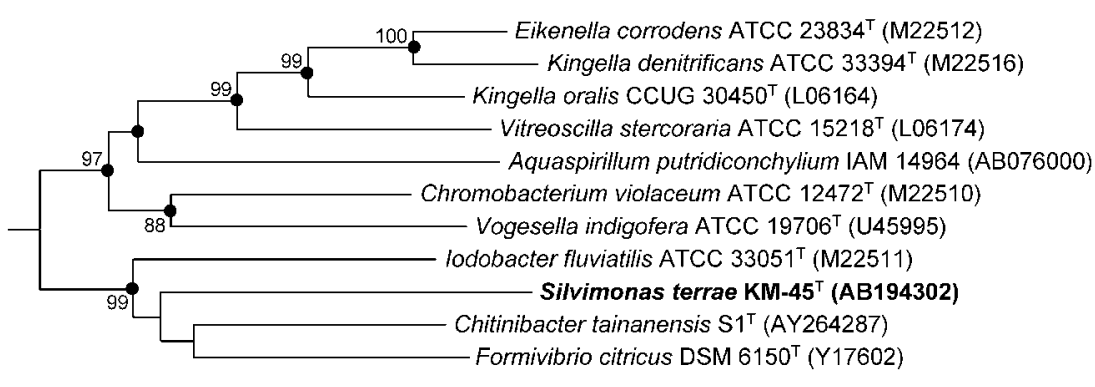

0.01
Fig. 1. Neighbour-joining tree showing the phylogenetic positions of Silvimonas terrae gen. nov., sp. nov. and its nearest neighbours based on 16S rRNA gene sequence analysis. Dots indicate generic branches that were also recovered by using maximumparsimony algorithms. Bootstrap values (expressed as percentages of 1000 replications) $>70 \%$ are shown at the branch points. Bar, 1 substitution per 100 nucleotide positions. sequence similarity, the closest recognized relatives were Chitinibacter tainanensis BCRC $17254^{\mathrm{T}} \quad(92 \cdot 4 \%)$, Formivibrio citricus DSM $6150^{\mathrm{T}}(91 \cdot 2 \%)$ and Iodobacter fluviatilis ATCC $33051^{\mathrm{T}}(88 \cdot 9 \%)$. This relationship between strain $\mathrm{KM}-45^{\mathrm{T}}$ and other members of the order 'Neisseriales' was also evident in the phylogenetic tree (Fig. 1). Strain $\mathrm{KM}-45^{\mathrm{T}}$ and the three strains discussed above formed a monophyletic clade with a high bootstrap value (99\%), which was supported by the neighbour-joining and maximum-parsimony methods employed.

Gram reaction was identified by the non-staining method as described by Buck (1982). Cell morphology was examined by light microscopy (Nikon) and transmission electron microscopy (Carl Zeiss) after negative staining with $1 \%$ $(\mathrm{w} / \mathrm{v})$ phosphotungstic acid. Catalase and oxidase tests were performed as outlined by Cappuccino \& Sherman (2002). Substrate utilization as sole carbon source and other physiological characteristics were determined with the API $32 \mathrm{GN}$ and API 20NE galleries according to the manufacturer's instructions (bioMérieux). Tests for anaerobic growth were performed in a serum bottle containing R2A broth supplemented with thioglycolate $\left(1 \mathrm{gl}^{-1}\right)$ and the upper air layer was substituted with nitrogen gas. Nitrateand nitrite-reduction tests were performed in serum bottles containing $\mathrm{R} 2 \mathrm{~A}$ broth supplemented with $\mathrm{KNO}_{3}(10 \mathrm{mM})$ and $\mathrm{NaNO}_{2}(10 \mathrm{mM})$, respectively, and reduction of nitrate and nitrite was monitored by using an ion chromatograph (model 790 personal IC; Metrohm) equipped with a conductivity detector and anion-exchange column (Metrosep Anion Supp 4; Metrohm). Degradation of DNA [using DNA agar (Difco) supplemented with $0.01 \%$ toluidine blue (Merck)], chitin, CM-cellulose, starch (Atlas, 1993), lipids (Kouker \& Jaeger, 1987) and xylan (Ten et al., 2004) was also investigated; reactions were read after 5 days. Growth at different temperatures and $\mathrm{pH}$ was assessed after 5 days incubation. Salt tolerance was tested on R2A medium supplemented with $1-10 \%(\mathrm{w} / \mathrm{v}) \mathrm{NaCl}$ after 5 days incubation. Duplicate antibiotic-sensitivity tests were performed by using filter-paper discs containing the following: streptomycin $\left(5,10\right.$ and $\left.15 \mu \mathrm{g} \mathrm{ml}^{-1}\right)$, tetracycline $(5,10$ and $\left.15 \mu \mathrm{g} \mathrm{ml}^{-1}\right)$, kanamycin $\left(1 \cdot 0,1 \cdot 5\right.$ and $\left.2 \cdot 0 \mathrm{mg} \mathrm{ml}^{-1}\right)$ and ampicillin (20, 30 and $50 \mu \mathrm{g} \mathrm{ml}^{-1}$ ) (Sigma). Discs were placed on R2A plates spread with $\mathrm{KM}-45^{\mathrm{T}}$ culture and were then incubated at $30^{\circ} \mathrm{C}$ for 5 days.
Cells of strain $\mathrm{KM}-45^{\mathrm{T}}$ are Gram-negative, rod-shaped, facultatively anaerobic and motile by means of a single polar flagellum (Fig. 2b). The colony grown on R2A agar plates (Difco) for 3 days was circular $(1 \cdot 3-2 \cdot 0 \mathrm{~mm}$ in diameter), convex and milky white. On R2A agar, strain $\mathrm{KM}-45^{\mathrm{T}}$ was able to grow at $10-40^{\circ} \mathrm{C}$, but not at 4 or $45^{\circ} \mathrm{C}$. Physiological characteristics of strain $\mathrm{KM}-45^{\mathrm{T}}$ are summarized in the genus and species descriptions and a comparison of selective
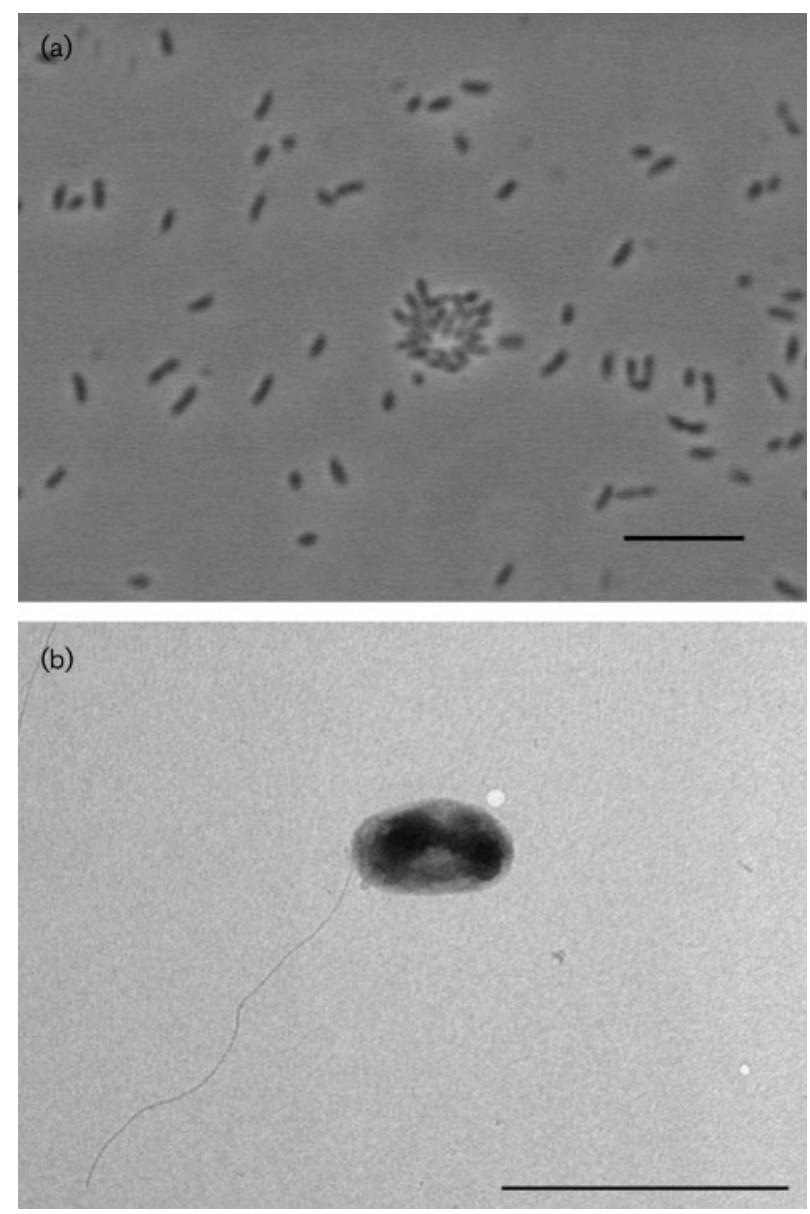

Fig. 2. (a) Phase-contrast photomicrograph of cells of Silvimonas terrae gen. nov., sp. nov. $\mathrm{KM}-45^{\top}$ and (b) negatively stained transmission electron micrograph of a single cell, showing one polar flagellum. Bars, (a) $10 \mu \mathrm{m}$; (b) $2 \mu \mathrm{m}$. 
characteristics with those of its nearest phylogenetic neighbours is given in Table 1 .

Quinones were extracted from cells grown in nutrient broth (Difco) and analysed as described by Komagata \& Suzuki (1987) using reversed-phase HPLC; cellular fatty acids were analysed in cells grown on trypticase soy agar (TSA, Difco) for 2 days. The cellular fatty acids were saponified, methylated and extracted according to the protocol of the Sherlock Microbial Identification system (MIDI, 1999). The fatty acids analysed by GC (Hewlett Packard 6890) were identified by the Microbial Identification software package. Mean values for each component were obtained from duplicate experiments.

Chromosomal DNA for determination of $\mathrm{G}+\mathrm{C}$ content was extracted from cells grown on a nutrient agar plate (Difco) as described by Moore (1995). RNA in the DNA solution was removed by incubation with a mixture of RNases $\mathrm{A}$ and $\mathrm{T} 1$ (each at $20 \mathrm{U} \mathrm{ml}^{-1}$ ) at $30^{\circ} \mathrm{C}$ for $1 \mathrm{~h}$. The $\mathrm{G}+\mathrm{C}$ content of the chromosomal DNA was analysed as described by Mesbah et al. (1989) using reversed-phase HPLC.

Strain $\mathrm{KM}-45^{\mathrm{T}}$ had Q-8 as its major quinone. The fatty acid profile of strain $\mathrm{KM}-45^{\mathrm{T}}$ included $\mathrm{C}_{16: 0}(33 \cdot 5 \pm 0 \cdot 8 \%)$, summed feature $4\left(\mathrm{C}_{16: 1} \omega 7 \mathrm{c} /\right.$ iso- $\left.\mathrm{C}_{15: 0} 2-\mathrm{OH}, 21 \cdot 8 \pm 1 \cdot 3 \%\right)$, summed feature $7\left(\mathrm{C}_{18: 1} \omega 7 c / \omega 9 t / \omega 12 t, 14 \cdot 7 \pm 0 \cdot 2 \%\right), \mathrm{C}_{17: 0}$ cyclo $(15 \cdot 3 \pm 1 \cdot 6 \%), \mathrm{C}_{14: 0}(6 \cdot 4 \pm 0 \cdot 3 \%), \mathrm{C}_{12: 0}(3 \cdot 6 \pm 0 \cdot 3 \%)$ and summed feature $3\left(\mathrm{C}_{14: 0} 3-\mathrm{OH} /\right.$ iso- $\left.\mathrm{C}_{16: 1} \mathrm{I}, 3 \cdot 4 \pm 0 \cdot 2 \%\right)$. The $\mathrm{G}+\mathrm{C}$ content of the genomic DNA of strain $\mathrm{KM}-45^{\mathrm{T}}$ was $58 \mathrm{~mol} \%$.
Phylogenetically, strain KM- $45^{\mathrm{T}}$ formed a novel lineage of descent within the 'Betaproteobacteria', and clustered with C. tainanensis BCRC $17254^{\mathrm{T}}(92 \cdot 4 \%$ 16S rRNA gene sequence similarity), F. citricus DSM $6150^{\mathrm{T}}(91 \cdot 2 \%)$ and I. fluviatilis ATCC $33051^{\mathrm{T}}(88 \cdot 9 \%)$. These low $16 \mathrm{~S}$ rRNA gene sequence similarities support the affiliation of strain $\mathrm{KM}-45^{\mathrm{T}}$ to a novel genus, which is also supported by its phenotypic and chemotaxonomic characteristics (Table 1). Strain $\mathrm{KM}-45^{\mathrm{T}}$ can be differentiated from C. tainanensis BCRC $17254^{\mathrm{T}}$ by its anaerobic growth, nitrate reduction and fatty acid profile. Distinguishing phenotypic characteristics of $F$. citricus DSM $6150^{\mathrm{T}}$ are inability to reduce nitrate into nitrite, inability to hydrolyse chitin and no $\beta$-glucosidase activity. I. fluviatilis ATCC $33051^{\mathrm{T}}$ can be differentiated from strain $\mathrm{KM}-45^{\mathrm{T}}$ on the basis of its relatively low $\mathrm{G}+\mathrm{C}$ content and other phenotypic characteristics (Table 1). On the basis of morphological, physiological and chemotaxonomic characteristics, together with data from $16 \mathrm{~S}$ rRNA gene sequence comparisons, strain $\mathrm{KM}-45^{\mathrm{T}}$ is considered to represent a novel genus and species, for which the name Silvimonas terrae gen. nov., sp. nov. is proposed.

\section{Description of Silvimonas gen. nov.}

Silvimonas (Sil.vi.mo' nas. L. fem. n. silva forest; L. fem. n. monas a unit, monad; N.L. fem. n. Silvimonas forest monad).

Cells are Gram-negative, rod-shaped $(1 \cdot 3-2 \cdot 0 \mu \mathrm{m}$ by $0 \cdot 5-$ $0 \cdot 8 \mu \mathrm{m})$ and facultatively anaerobic. They occur singly or in pairs (Fig. 2a) and are motile by means of a single polar flagellum (Fig. 2b). Colonies on R2A are circular, convex

Table 1. Selective differential phenotypic and chemotaxonomic characteristics of Silvimonas terrae gen. nov., sp. nov. and its nearest phylogenetic neighbours

Taxa: 1, Silvimonas terrae KM- $45^{\mathrm{T}} ; 2$, Chitinibacter tainanensis $\mathrm{BCRC} 17254^{\mathrm{T}}$; 3, Formivibrio citricus DSM $6150^{\mathrm{T}} ; 4$, Iodobacter fluviatilis NCTC $11159^{\mathrm{T}}$. +, Positive; - , negative result; Tr, trace.

\begin{tabular}{|c|c|c|c|c|}
\hline Characteristic & 1 & $2^{*}$ & $3 \dagger$ & $4 \ddagger$ \\
\hline Anaerobic growth & + & - & + & + \\
\hline Nitrate reduction to $\mathrm{NO}_{2}^{-}$ & + & - & - & + \\
\hline Nitrite reduction to $\mathrm{N}_{2}$ & - & - & - & + \\
\hline Chitin hydrolysis $\$$ & + & + & - & Weak (delayed) \\
\hline$\beta$-Glucosidase & + & - & - & + \\
\hline \multicolumn{5}{|l|}{ Cellular fatty acid ( $\%$ of total): } \\
\hline $\mathrm{C}_{12: 0} 3-\mathrm{OH}$ & - & $4 \cdot 1 \pm 0 \cdot 2$ & $\operatorname{Tr}$ & $2 \cdot 5 \pm 0 \cdot 5$ \\
\hline $\mathrm{C}_{14: 0}$ & $6 \cdot 4 \pm 0 \cdot 3$ & $\operatorname{Tr}$ & $2 \cdot 2$ & $8 \cdot 4$ \\
\hline $\mathrm{C}_{14: 0} 3-\mathrm{OH}$ & - & - & $9 \cdot 5$ & - \\
\hline 10-Methyl $\mathrm{C}_{19: 0}$ & - & $1 \cdot 7 \pm 0 \cdot 3$ & - & - \\
\hline Growth at $40^{\circ} \mathrm{C}$ & + & + & - & - \\
\hline DNA G $+\mathrm{C}$ content $(\mathrm{mol} \%)$ & 58 & 56 & 61 & $50-52$ \\
\hline Major quinone & Q-8 & Q-8 & Q-8 & Q-8 \\
\hline
\end{tabular}

${ }^{*}$ Data taken from Chern et al. (2004).

$\dagger$ Data taken from Tanaka et al. (1991), except for chitin hydrolysis and cellular fatty acids (this study). ¥Data taken from Logan (1989), except for chitin hydrolysis and cellular fatty acids (this study).

$\S$ Data for chitin hydrolysis and cellular fatty acids, except those for Silvimonas terrae, were taken from Chern et al. (2004). 
and milky white. Catalase and oxidase are positive. The predominant quinone is Q-8. Major cellular fatty acids are $\mathrm{C}_{16: 0}$, summed feature $4\left(\mathrm{C}_{16: 1} \omega 7 c /\right.$ iso- $\left.\mathrm{C}_{15: 0} 2-\mathrm{OH}\right)$, summed feature $7\left(\mathrm{C}_{18: 1} \omega 7 c / \omega 9 t / \omega 12 t\right)$ and $\mathrm{C}_{17: 0}$ cyclo. Based on 16S rRNA gene sequence analysis, Silvimonas belongs to the 'Betaproteobacteria'. The type species is Silvimonas terrae.

\section{Description of Silvimonas terrae sp. nov.}

Silvimonas terrae (ter'rae. L. gen. n. terrae of the earth).

In addition to the characteristics that define the genus, it has the following characteristics. Growth is observed at temperatures of $15-40{ }^{\circ} \mathrm{C}$ (optimum $25-30^{\circ} \mathrm{C}$ ) and at $\mathrm{pH}$ values of $6 \cdot 0-8 \cdot 0$ (optimum $\mathrm{pH} 7 \cdot 0$ ). Growth occurs in the absence of $\mathrm{NaCl}$ and in the presence of $2.0 \%(\mathrm{w} / \mathrm{v}) \mathrm{NaCl}$; no growth is observed above $4.0 \%(\mathrm{w} / \mathrm{v}) \mathrm{NaCl}$. Positive for production of acid from glucose, reduction of nitrate to nitrite and production of $\beta$-glucosidase and $\beta$-galactosidase. It can degrade chitin, starch, CM-cellulose and DNA, but cannot degrade lipid or xylan. Negative for reduction of nitrite to nitrogen, production of indole, arginine dihydrolase, urease and protease activities (gelatin hydrolysis). The following compounds are assimilated as sole carbon sources: L-fucose, L-arabinose, maltose, D-mannose, Lrhamnose, D-sucrose, mannitol, $\mathrm{N}$-acetylglucosamine and gluconate. The following compounds are not assimilated as sole carbon sources: D-ribose, 3-hydroxybutyrate, acetate, adipate, citrate, 3-hydroxybenzoate, malate, valerate, 4-hydroxybenzoate, 5-ketogluconate, caprate, itaconate, D-sorbitol, lactate, malonate, phenylacetate, suberate, L-alanine, L-proline, L-serine, inositol, D-melibiose, glycogen and salicin. Resistant to $30 \mu \mathrm{g}$ ampicillin $\mathrm{ml}^{-1}, 15 \mu \mathrm{g}$ tetracycline $\mathrm{ml}^{-1}$ and $15 \mu \mathrm{g}$ streptomycin $\mathrm{ml}^{-1}$, but sensitive to $1 \mathrm{mg}$ kanamycin $\mathrm{ml}^{-1}$. Major cellular fatty acids are $\mathrm{C}_{16: 0}$, summed feature $4\left(\mathrm{C}_{16: 1} \omega 7 c /\right.$ iso- $\mathrm{C}_{15: 0}$ 2-OH), summed feature $7\left(\mathrm{C}_{18: 1} \omega 7 c / \omega 9 t / \omega 12 t\right)$ and $\mathrm{C}_{17: 0}$ cyclo. The $\mathrm{G}+\mathrm{C}$ content of the genomic DNA of the type strain is $58 \mathrm{~mol} \%$.

The type strain, KM- $45^{\mathrm{T}} \quad\left(=\mathrm{KCTC} \quad 12358^{\mathrm{T}}=\mathrm{NBRC}\right.$ $100961^{\mathrm{T}}$ ), was isolated from forest soil collected near KAIST, Daejeon, South Korea.

\section{Acknowledgements}

This work was supported by the Eco-Technopia-21, Ministry of Environment and the 21C Frontier Microbial Genomics and Application Center Program, Ministry of Science and Technology (grant MG05-0101-4-0), Republic of Korea.

\section{References}

Atlas, R. M. (1993). Handbook of Microbiological Media, 2nd edn. Edited by L. C. Parks. Boca Raton, FL: CRC Press.
Buck, J. D. (1982). Nonstaining (KOH) method for determination of Gram reactions of marine bacteria. Appl Environ Microbiol 44, 992-993.

Cappuccino, J. G. \& Sherman, N. (2002). Microbiology: a Laboratory Manual, 6th edn. San Francisco: Benjamin Cummings.

Chern, L.-L., Stackebrandt, E., Lee, S.-F., Lee, F.-L., Chen, J.-K. \& Fu, H.-M. (2004). Chitinibacter tainanensis gen. nov., sp. nov., a chitin-degrading aerobe from soil in Taiwan. Int J Syst Evol Microbiol 54, 1387-1391.

Felsenstein, J. (1985). Confidence limits on phylogenies: an approach using the bootstrap. Evolution 39, 783-791.

Fitch, W. M. (1971). Toward defining the course of evolution: minimum change for a specific tree topology. Syst Zool 20, 406-416.

Hall, T. A. (1999). BioEdit: a user-friendly biological sequence alignment editor and analysis program for Windows 95/98/NT. Nucleic Acids Symp Ser 41, 95-98.

Kim, M. K., Im, W.-T., Ohta, H., Lee, M. \& Lee, S.-T. (2005). Sphingopyxis granuli sp. nov., a $\beta$-glucosidase-producing bacterium in the family Sphingomonadaceae in $\alpha-4$ subclass of the Proteobacteria. J Microbiol 43, 152-157.

Kimura, M. (1983). The Neutral Theory of Molecular Evolution. Cambridge: Cambridge University Press.

Komagata, K. \& Suzuki, K. (1987). Lipid and cell wall analysis in bacterial systematics. Methods Microbiol 19, 161-206.

Kouker, G. \& Jaeger, K.-E. (1987). Specific and sensitive plate assay for bacterial lipases. Appl Environ Microbiol 53, 211-213.

Kumar, S., Tamura, K. \& Nei, M. (2004). MEGA3: integrated software for molecular evolutionary genetics analysis and sequence alignment. Brief Bioinform 5, 150-163.

Logan, N. A. (1989). Numerical taxonomy of violet-pigmented, gram-negative bacteria and description of Iodobacter fluviatile gen. nov., comb. nov. Int J Syst Bacteriol 39, 450-456.

Mesbah, M., Premachandran, U. \& Whitman, W. B. (1989). Precise measurement of the $\mathrm{G}+\mathrm{C}$ content of deoxyribonucleic acid by highperformance liquid chromatography. Int J Syst Bacteriol 39, 159-167. MIDI (1999). Sherlock Microbial Identification System, Operating Manual, version 3.0. Newark, DE: MIDI, Inc.

Moore, D. D. (1995). Preparation and analysis of DNA. In Current Protocols in Molecular Biology. Edited by F. W. Ausubel, R. Brent, R. E. Kingston, D. D. Moore, J. G. Seidman, J. A. Smith \& K. Struhl. New York: Wiley.

Saitou, N. \& Nei, M. (1987). The neighbor-joining method: a new method for reconstructing phylogenetic trees. Mol Biol Evol 4, 406-425.

Tanaka, K., Nakamura, K. \& Mikami, E. (1991). Fermentation of $S$-citramalate, citrate, mesaconate, and pyruvate by a Gram-negative strictly anaerobic non-spore-former, Formivibrio citricus gen. nov., sp. nov. Arch Microbiol 155, 491-495.

Ten, L. N., Im, W.-T., Kim, M.-K., Kang, M.-S. \& Lee, S.-T. (2004). Development of a plate technique for screening of polysaccharidedegrading microorganisms by using a mixture of insoluble chromogenic substrates. J Microbiol Methods 56, 375-382.

Thompson, J. D., Gibson, T. J., Plewniak, F., Jeanmougin, F. \& Higgins, D. G. (1997). The CLUSTAL_X windows interface: flexible strategies for multiple sequence alignment aided by quality analysis tools. Nucleic Acids Res 25, 4876-4882. 